\title{
How does HCI research affect education programs? A study in the Brazilian context
}

\author{
Isabela Gasparini, ${ }^{1}$ Simone Diniz Junqueira Barbosa, ${ }^{2}$ Milene Selbach Silveira, ${ }^{3}$ \\ Sílvia Amélia Bim, ${ }^{4}$ Clodis Boscarioli ${ }^{5}$ \\ ${ }^{1}$ Departamento de Ciência da Computação, UDESC, SC, Brazil \\ isabela.gasparini@udesc.br \\ ${ }^{2}$ Departamento de Informática, PUC-Rio, RJ, Brazil \\ simone@inf.puc-rio.br \\ ${ }^{3}$ PUCRS, Faculdade de Informática, Porto Alegre, RS, Brazil \\ milene.silveira@pucrs.br \\ ${ }^{4}$ Departamento de Informática, UTFPR, Curitiba, PR, Brazil \\ sabim@utfpr.edu.br \\ ${ }^{5}$ Departamento de Ciência da Computação, UNIOESTE, Cascavel, PR, Brazil \\ clodis.boscarioli@unioeste.br
}

\begin{abstract}
This paper presents a comparative analysis based on two independent studies of Human-Computer Interaction (HCI) education and research in Brazil. The first study was conducted to understand how HCI has been taught in Brazil, via a survey responded by 114 educators and researchers in the country. The second study analyzed the scientific production of HCI in Brazil from a fifteenyear analysis of full papers published on the Brazilian Symposium on Human Factors in Computing Systems (IHC). Our analysis is based on data-driven visual exploration, and it can help to get insights from the data and to identify how $\mathrm{HCI}$ research in Brazil relates to our education programs. We believe this kind of analysis can shed some light in the evolution of $\mathrm{HCI}$ in other countries.
\end{abstract}

Keywords: HCI education in Brazil, HCI research in Brazil.

\section{Introduction}

In 2006, a group of professors and researchers met during the Brazilian Symposium on Human Factors in Computing Systems (IHC) to discuss a syllabus for HCI courses, forming a working group on $\mathrm{HCI}$ education [1]. In that year, the working group established a reference syllabus, which has been adopted in undergraduate courses in several Brazilian universities. Since 2010, the Special Interest Group on HumanComputer Interaction (CEIHC) of the Brazilian Computer Society (SBC) has promoted a series of Workshops on HCI Education (WEIHC) alongside the IHC conference. The workshops offer an opportunity for faculty, researchers and students to discuss relevant issues about teaching, educational experiences, teaching materials and HCI curriculum. In 2014, based on previous survey and discussions held in working groups during the WEIHC, and considering the ACM Computer Science Curricula 
(2013) and the Curriculum Guidelines for Undergraduate Degree Programs in Information Systems (AIS and ACM 2010), the syllabus described in Silveira and Prates [1] was revised and new syllabi were proposed for Information Systems, Computer Science and Computer Engineering courses [2].

When devising syllabi, a major challenge of education in all areas is that undergraduate students are educated to tackle problems that may not yet exist before they graduate. As such, in order to form good human-computer (HCI) professionals, we believe that professors should expose undergraduate students not only to established HCI topics, but also to some current research topics.

In this paper, we investigate the relationship of topics addressed by HCI research in Brazil with topics of Brazilian HCI education programs. We have based our analysis on two independent studies: the first analyzed the HCI scientific production in Brazil; and the second investigated how HCI has been taught in Brazil.

This paper is structured as follows: Section 2 presents works related with HCI education. In Section 3, we describe the studies that based our analysis. Sections 4 and 5 discuss the analysis, and Section 6, the final considerations.

\section{Related Works}

The first HCI curriculum recommended by ACM SIGCHI was published in 1992 [3]. Almost twenty years later, in 2011, as an attempt to address requests for "guidance and insight into which HCI methods and skills can or should be taught to new graduates and incoming and current staff members" [4], ACM SIGCHI launched a research project "to understand emerging subjects, topics, and challenges in the field of HCI". The goal of the project is to characterize current HCI education and provide recommendations for academics and practitioners [5].

The project encompasses a review of core and elective HCI courses for both academic students and professionals; a review of textbooks and related teaching materials; and interviews, surveys and focus groups with students, educators, and practitioners worldwide. The survey was first translated to Portuguese and Chinese, and has been taken by over 500 respondents worldwide. It now has also versions in French and Spanish, to broaden the population sample.

As reported in Churchill et al. [5], methods have a prominent role in HCI education, as 8 of the 11 most highly ranked topics (at least 4.46 on a $1-5$ scale) were about design or empirical research methodologies, namely: general qualitative research; interaction design; observation; interviews; prototyping (general); analyzing and applying research; general empirical research; and, paper/low-fidelity prototyping.

Churchill et al. [5] hypothesize that methods were highly valued because "In an era of rapidly emerging technologies it is more important to help students develop critical skills, the ability to frame problems and a keen sensibility around what methods to use when than to teach classic principles of desktop design."

Qualitative and quantitative research methods were viewed as complementary, and not mutually exclusive. There was little consensus, however, as to whether qualitative research methods should be taught within a technical or a social sciences curriculum. 
In reviewing the syllabi, Churchill et al. [5] found that all courses covered the following areas: Foundational theory; Current topics; Tools and technologies; Design research methods; Empirical research methods; and Design Studio. In those courses, students were required to complete one of two kinds of projects: Design, build and test an application; and, Conduct and report on empirical research.

From the syllabi review, Churchill et al. [4] uncovered five course patterns:

- Introduction to HCI model = Foundational theory + Design research methods + Design, build and test an application;

- Graduate methods = design research methods and/or empirical research \& methods + conduct and report on empirical research;

- Cycle-based survey model = current topics + empirical research methods + conduct and report on empirical research;

- Standard Technology Course model = Tools and technologies + Design, build and test an application;

- Advanced topics in HCI model = current topics + tools and technologies.

In 2006, CEIHC/SBC proposed a reference syllabus (Figure 1) that closely follows the first pattern ("Introduction to HCI model", which has been adopted in undergraduate courses in several Brazilian universities [1].

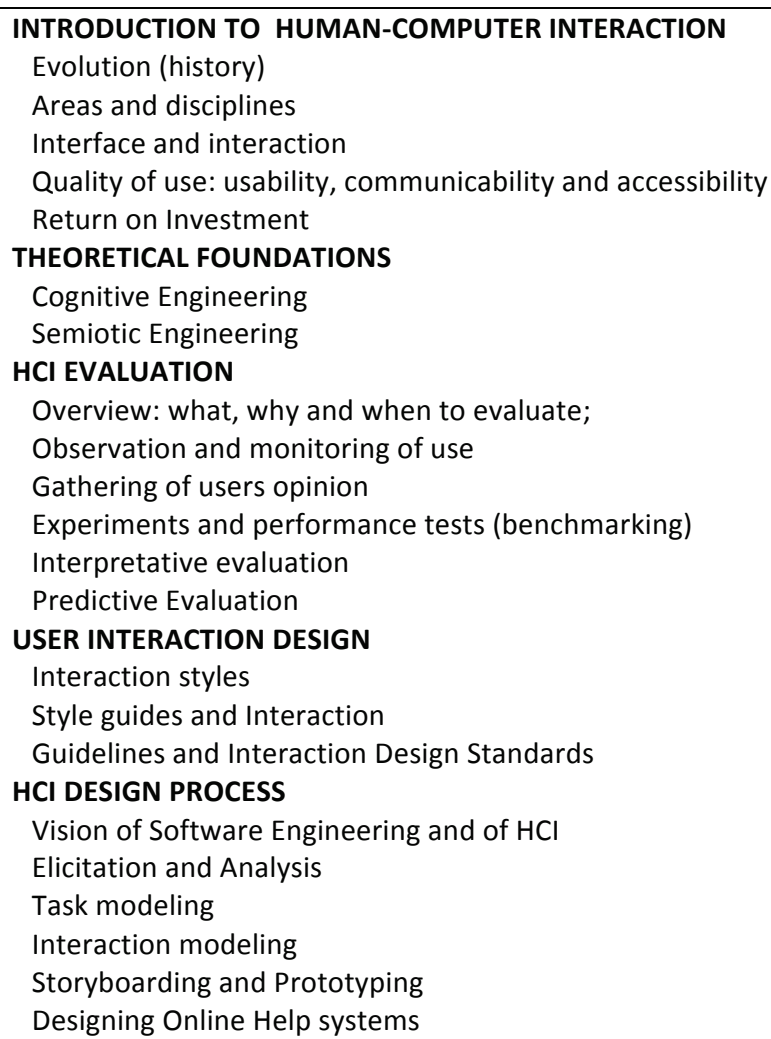

Figure 1.Topics recommended in the 2006 syllabus. 
The ACM SIGCHI research project on HCI Education also uncovered five challenges that HCI educators need to address, related to the following themes [5]:

1. finding a balance between unity and interdisciplinary - how HCI is characterized as a discipline.

2. divide between academia and industry - the different skill sets needed to perform in academia and in practice.

3. the role of computer science (CS) in HCI education - in which ways and to what extent CS knowledge contributes to learning HCI.

4. a standardized or flexible curriculum - addressing multiple areas of practice may enable students to go to the industry and work on a variety of projects.

5. breadth and depth in HCI - a broad curriculum may lead to diverse ideas from multiple perspectives, and also to a more unified theoretical perspective, whereas depth is mainly associated with rigor.

As HCI becomes increasingly multidisciplinary, HCI Education starts exploring fields like anthropology and social sciences in search of methods and theories that can inform HCI work, such as a range of qualitative research methods. Moreover, the scores given by professors and students varied widely, which also points to the need of a flexible curriculum that can be adjusted to the students' profiles (for instance, future researchers versus future practitioners).

One way to improve HCI practices is by improving HCI education. In this direction, researches are being conducted on HCI Education to comprehend their status, contents and teaching strategies in different countries. For instance, Graham [6] conducted a survey on the teaching and assessment methods and recommended literature for HCI courses. Yammiyavar [7] brings the evolution of the HCI educational institutions and research collaborations in usability (areas, topics and events) in India, highlighting the need for more researchers in this field. The same reality takes place in Brazil, as described in the next section.

\section{Independent Studies of the Brazilian HCI Community}

In this section we describe the studies we conducted about the HCI community in Brazil. Section 3.1 presents the research on HCI Brazilian Symposium papers and Section 3.2 describes the research on HCI education in Brazil.

\subsection{HCI Brazilian Symposium Papers}

The Brazilian Symposium on Human Factors in Computing Systems (IHC) is the major HCI conference in Brazil and it is supported by the HCI Special Interest Group of the Brazilian Computer Society. Starting in 1998, the first four editions of IHC were held in the format of workshops and, since then, the symposium became the primary forum for the regular meeting of the Brazilian community of researchers, teachers and professionals who are dedicated to HCI in Brazil [8]. The first event was held in 2 days with about 70 participants; the current event lasts 4 to 5 days, with about 200 participants. 
In a research investigating the scientific production on HCI in Brazil [9], the collection of full papers published at IHC was analyzed. ${ }^{1}$ Data were collected from the proceedings of the conferences, made available by their coordinators. Then, a webbased system for data gathering was created, and for each paper the following information was stored: (a) basic data: year of the conference, paper title, language, theme of the conference, the keywords attributed by the authors of the paper, abstract, fields of the ACM template (keywords, categories and general term); (b) information about the author: name of each paper's authors, e-mail, an acronym of the institutions, department/institute, country of the researchers, state (if the participants are in Brazil); and (c) record of each individual reference of the paper. More detail about this research and some preliminary analysis can be found in Gasparini et al. [9].

\subsection{Surveys on HCI Education in Brazil}

In order to understand how HCI has been taught in Brazil, three surveys have been applied in the last years. In 2009 the focus was the HCI courses being taught countrywide [10]. In 2012, another survey was conducted in response to a SIGCHI demand [11]. The last one targeted a broader audience, not taking into account specificities of the Brazilian context. This way, in 2013, aiming to deepen the analysis and, mainly, taking into consideration the specificities of the Brazilian context, we designed and applied a new survey [12], through which we collected information on the HCI courses at different levels (undergraduate, Master's, Doctorate, and others); where they were taught and whether they were mandatory; the course topics; the number of hours dedicated to each topic; the recommended bibliography; and the instructors' profiles.

The results of these surveys were collected through online questionnaires and participants were invited via mailing lists and social networks. Despite the efforts to achieve a multidisciplinary group of participants most of them had a computing-based background.

The respondents were from all Brazilian geographical regions, giving an interesting overview of HCI Education in Brazil, mainly from the perspective of Computer Science courses. Notwithstanding, we cannot make any claims regarding its statistical validity, since the population of HCI professors, researchers, students and practitioners is unknown. Table 1 shows the number of participants in each survey.

Table 1. Number of respondents in each survey.

\begin{tabular}{|c|c|c|c|}
\hline Year of the survey & 2009 & 2012 & 2013 \\
\hline Number of respondents & 89 & 109 & $114^{2}$ \\
\hline
\end{tabular}

Concerning the degree level of the professors/lecturers, the survey applied in 2009 indicates that $55 \%$ were PhDs and $38 \%$ had a master's course, and $67.4 \%$ of the re-

1 As this research was presented in IHC 2013, the proceedings of 2014 were not included in the evaluation process.

2 Although the 2013 survey had 114 respondents, only 74 were considered valid, i.e., taught at least one course. 
spondents listed HCI as one of their main research areas [10]. The majority of the courses taught (141 in total) were for undergraduate degrees (57\%), whereas $23 \%$ for graduate degrees, $18 \%$ were offered both to undergraduate and graduate programs and $2 \%$ did not answer. Most courses $(57 \%)$ were classified as introductory courses, while $28 \%$ were considered advanced and finally $15 \%$ were HCI modules and were taught mainly in Software Engineering and Computer Graphics courses.

In 2013, only $35 \%$ (26 out of 74 valid respondents) claimed to have a Master's, Doctorate, or lato sensu degree in HCI (6 responses $\left.{ }^{3}\right)$ or in Computer Science, with an emphasis on HCI (24 responses). The respondents' teaching experience averaged 4.7 years. It reinforces that $\mathrm{HCI}$ is still a new field in Brazil, because most of the surveyed $\mathrm{HCI}$ lecturers do not have advanced degrees in $\mathrm{HCI}$, but in other areas, such as other emphases of Computer Science. None of the mentioned HCI undergraduate courses (70 in total) requires prerequisites, and most of them are mandatory within their majors: $63 \%$ in Computer Science, $86 \%$ in Information Systems and $71 \%$ in Computer Engineering. However, their study load is still low, 75 hours on average, which means one course during the entire undergraduate program, which has on average a total of 3200 hours.

Differently from the 2009 and 2013 surveys, one of the aims of the survey applied in 2012 was to investigate the respondents' opinions about challenges related to HCI education. All respondents (professors and researchers, students, and practitioners) agree that the following topics are challenges in the Brazilian context [11]:

- Adopting a common curriculum;

- Advocating the importance of HCI to computer scientists;

- How to approach HCI as a complex interdisciplinary field;

- Sufficient practice in HCI;

- Sufficient theory in HCI;

- Building on previous education to reach mastery; and

- Fostering collaboration between different programs.

The results about the curricula, syllabi and bibliography (recommended literature) obtained by the 2013 survey are compared with the results of the investigation about the IHC papers in the next section.

\subsection{Study Procedure}

In order to analyze the interplay between HCI research and education, we surveyed the full papers published in our national IHC conference series ${ }^{4}$ and examined the responses of the 2013 survey on HCI education, gathering the keywords/topics and bibliography. ${ }^{5}$

\footnotetext{
${ }^{3}$ Note that a respondent could have multiple degrees in different areas, so the total number of responses exceeds the total number of respondents.

${ }^{4}$ We have included the entire full paper collection in our analysis, authored by either Brazilian or international researchers.

${ }^{5}$ For a complementary analysis of the 2013 survey, see [12].
} 
We cross-referenced the keywords and topics in the papers and courses, highlighting similarities and differences of occurrences, such as: keywords/topics highly mentioned on both paper and courses; keywords mentioned in papers, but not in courses; and topics mentioned in courses, but not in papers. When analyzing the bibliography, we also noted most frequently cited references and recommended textbooks. Finally, we present a regional distribution of survey respondents and published papers, relating them with the regions where IHC was held.

\section{Discussion}

In this section, we analyze the study results, discussing the course topics and paper keywords (Section 4.1), the bibliography recommended in courses and cited in the papers (Section 4.2), and an evolution of HCI research in the country (Section 4.3).

\subsection{Topics and Keywords}

Considering the keywords present in three or more IHC papers (Figure 2), we could observe in the first years the predominance of general terms, such as human-computer interaction, interface, usability, ergonomics design (and their variations: interface design, usability evaluation or human-computer interface, for instance). But we could also observe - since the first editions of IHC - the prevalence of a specific keyword, Semiotic Engineering, which is an HCI theory born in Brazil [13]. The growth and maturity of the Brazilian HCI research and researchers could be observed by the specificity and diversity of topics in recent editions of the conference. In Figure 2, terms are listed in number of appearance; darker squares indicate high density, and lighter squares indicate low density.

To contrast the paper keywords with the topics of Brazilian HCI undergraduate courses, we depict in Figure 3 the topics that were either mentioned in both courses and papers, or in more than ten courses. From the three most frequently mentioned keywords in the papers (Semiotic Engineering, Usability Evaluation, and Accessibility), we highlight two that also occur frequently in courses: Semiotic Engineering and Accessibility, which are detailed in Section 5.

Considering now the topics mentioned in courses, we find the predominance of more general terms, such as Evaluation, Usability, and Interface Design, with 28, 18, 18 mentions, respectively.

Some topics present in the paper keywords (Figure 2) were quite specific and did not appear explicitly in the undergraduate courses (Figure 3), either because they may be embedded in other topics (e.g. Personas and Cultural Issues in Interaction or Participatory Design), or because they are novel or specific research topics that would not fit in introductory courses (such as Social Networks). As expected, some topics were present in undergraduate courses and not in the paper keywords, for instance: Storyboarding and Prototyping, Interaction Styles, Design Patterns and Guidelines, Style Guides, Analysis and Elicitation, and Cognitive Engineering. 


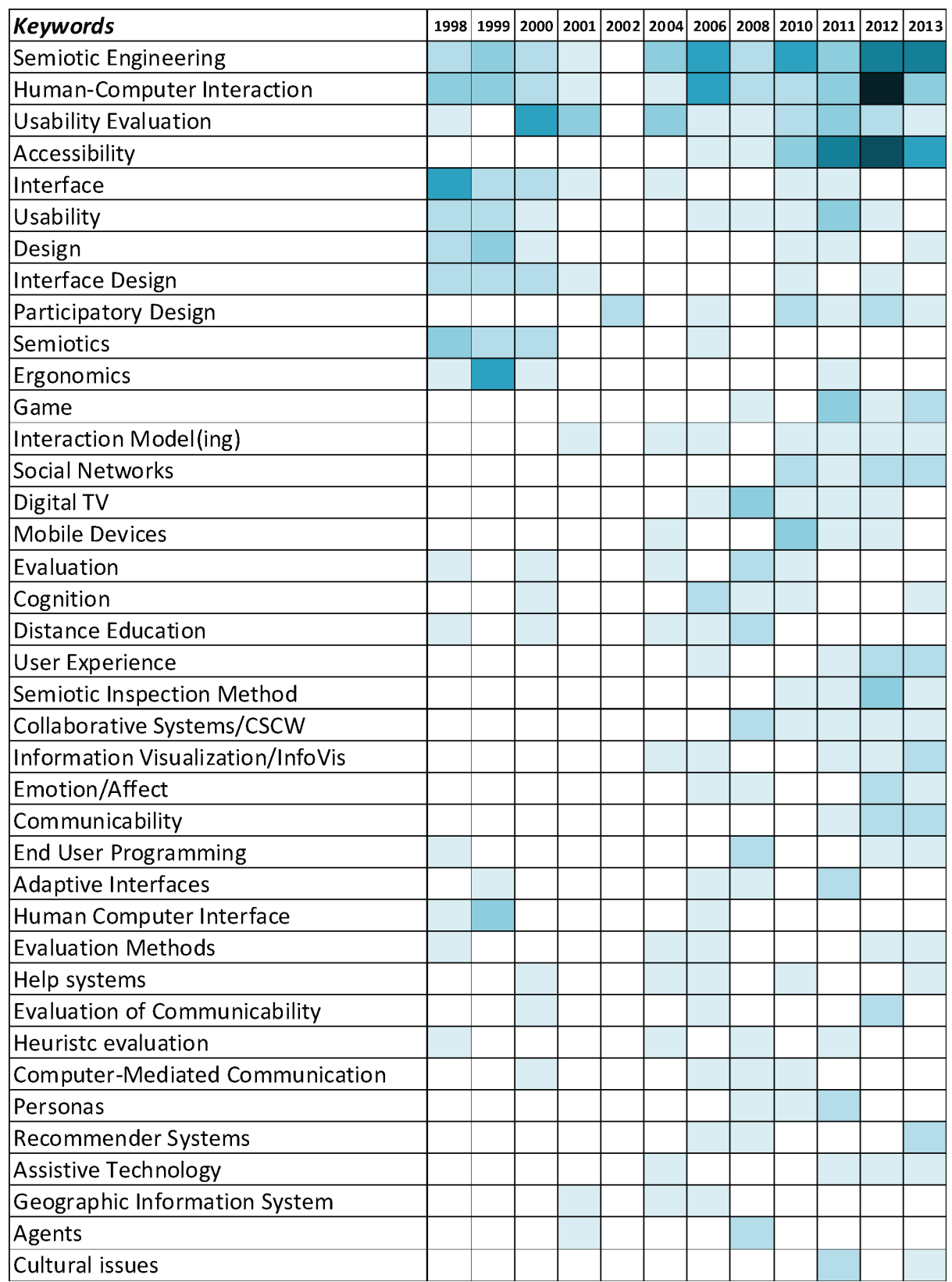

Figure 2. Keywords present in three or more IHC papers 


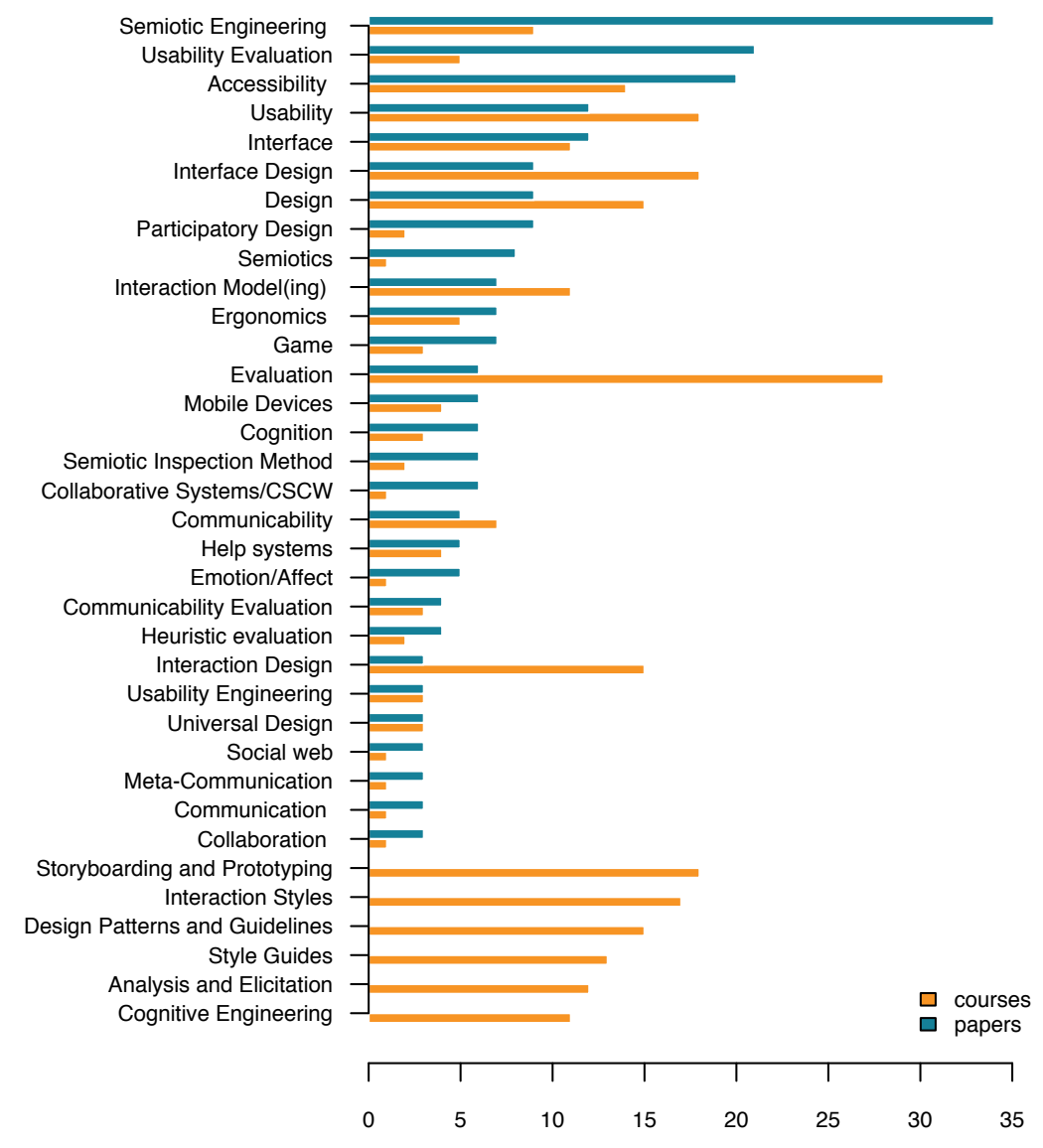

Figure 3. Topics taught in undergraduate courses and present in the papers.

\subsection{Recommended Bibliography}

In the 2013 survey, respondents were asked to present all textbooks, resources and/or references they use in their HCI-related undergraduate courses.

The survey collected 147 different references, mainly books. However, despite the large number of references found, significantly fewer references -only 38-were cited by more than one respondent. Some references were used both in English and Portuguese (because diverse textbooks are translated to Portuguese); other books only in English (they do not have a translation to Portuguese); and still others in Portuguese, written by Brazilian authors. Some references also have different editions.

We compared this set of references to the number of times they were cited in full papers at IHC, in order to explore their similarities. We continue our analysis including only the references that appeared at least three times either in the survey or in the papers (Table 2). 
Table 2. References cited: Education survey (S) and IHC papers (P).

\begin{tabular}{|c|c|c|c|c|}
\hline$\#$ & $\mathrm{~S}$ & $\mathrm{P}$ & Lang & Description \\
\hline 1 & 44 & 25 & $\begin{array}{l}\text { EN/ } \\
\text { PT }\end{array}$ & $\begin{array}{l}\text { PREECE, J.; ROGERS, Y.; SHARP, H. Interaction design: beyond hu- } \\
\text { man-computer interaction. John Wiley \& Sons, } 2013 \text { (+ previous editions) }\end{array}$ \\
\hline 2 & 27 & 6 & PT & $\begin{array}{l}\text { BARBOSA, S.D.J.; SILVA, B.S. Interação Humano-Computador. Cam- } \\
\text { pus/Elsevier, 2010. }\end{array}$ \\
\hline 3 & 15 & 11 & PT & $\begin{array}{l}\text { ROCHA, H.V.; BARANAUSKAS, M.C.C. Design e Avaliação de Inter- } \\
\text { faces Humano-Computador. Nied/Unicamp, } 2003 .\end{array}$ \\
\hline 4 & 14 & 20 & $\mathrm{EN}$ & $\begin{array}{l}\text { SHNEIDERMAN, B. Designing the user interface. Prentice Hall, 2009. (+ } \\
\text { previous editions) }\end{array}$ \\
\hline 5 & 9 & 3 & $\begin{array}{l}\mathrm{EN} / \\
\mathrm{PT}\end{array}$ & $\begin{array}{l}\text { NIELSEN, J.; LORANGER, H. Usabilidade na Web - Projetando Websi- } \\
\text { tes com Qualidade. Campus, 2007. (Obs.: translation of "Prioritizing Web } \\
\text { Usability") }\end{array}$ \\
\hline 6 & 7 & 5 & PT & $\begin{array}{l}\text { CYBIS, W.; BETIOL, A.H.; FAUST, R. Ergonomia e Usabilidade: co- } \\
\text { nhecimentos, métodos e aplicações. Novatec, 2010. (+ previous editions) }\end{array}$ \\
\hline 7 & 7 & 26 & $\begin{array}{l}\mathrm{EN} / \\
\mathrm{PT}\end{array}$ & $\begin{array}{l}\text { NIELSEN, J. Usability Engineering. Chestnut Hill, MA: Academic Press, } \\
1993 .\end{array}$ \\
\hline 8 & 5 & 2 & PT & $\begin{array}{l}\text { DIAS, C. Usabilidade na Web - Criando Portais Mais Acessíveis. Alta- } \\
\text { Books, 2007. (+ previous editions) }\end{array}$ \\
\hline 9 & 5 & 10 & PT & $\begin{array}{l}\text { PRATES, R. O.; BARBOSA, S.D.J. Introdução à Teoria e Prática da IHC } \\
\text { fundamentada na Engenharia Semiótica. JAI/CSBC. SBC, } 2007 .\end{array}$ \\
\hline 10 & 4 & 0 & $\begin{array}{l}\mathrm{EN} / \\
\mathrm{PT}\end{array}$ & $\begin{array}{l}\text { BENYON, D. Interação Humano-Computador. Pearson, 2011. (Obs.:2nd } \\
\text { edition) (Obs.: translation of "Designing Interactive Systems") }\end{array}$ \\
\hline 11 & 4 & 8 & $\mathrm{EN}$ & $\begin{array}{l}\text { DIX, A.; FINLAY, J.; ABOWD, G.; BEALE, R. Human-Computer Inter- } \\
\text { action. Prentice Hall, 2004. (Obs.: and/or previous editions) }\end{array}$ \\
\hline 12 & 4 & 8 & $\begin{array}{l}\text { EN/ } \\
\text { PT }\end{array}$ & $\begin{array}{l}\text { NIELSEN, J. Projetando Websites. Campus, 2000. (Obs.: translation of } \\
\text { "Designing Web Usability") }\end{array}$ \\
\hline 13 & 4 & 3 & PT & $\begin{array}{l}\text { PRATES, R.O.; BARBOSA, S.D.J. Avaliação de Interfaces de Usuário - } \\
\text { Conceitos e Métodos. JAI/CSBC. SBC, } 2003 .\end{array}$ \\
\hline 14 & 4 & 7 & $\mathrm{EN}$ & $\begin{array}{l}\text { RUBIN, J.; CHISNELL, D. Handbook of Usability Testing: How to Plan, } \\
\text { Design, and Conduct Effective Tests. Wiley, 2008. (+ previous editions) }\end{array}$ \\
\hline 15 & 4 & 5 & $\begin{array}{l}\text { EN/ } \\
\text { PT }\end{array}$ & $\begin{array}{l}\text { NORMAN, D.A. The Psychology of Everyday Things. Basic Books, } 1988 \\
\text { // The Design of Everyday Things, Basic Book, } 1998 \text {. }\end{array}$ \\
\hline 16 & 3 & 25 & EN & $\begin{array}{l}\text { de SOUZA, C.S. The semiotic engineering of human computer interac- } \\
\text { tion. The MIT Press, } 2005 \text {. }\end{array}$ \\
\hline 17 & 3 & 0 & $\mathrm{EN}$ & $\begin{array}{l}\text { NIELSEN, J.; Tahir, M. Homepage: Usabilidade } 50 \text { sites descontruídos. } \\
\text { Campus, 2002. (Obs.: translation of "Homepage Usability: } 50 \text { Websites } \\
\text { Deconstructed") }\end{array}$ \\
\hline 18 & 3 & 0 & $\mathrm{EN}$ & $\begin{array}{l}\text { WILLIAMS, R. Design para quem não é designer: noções básicas de } \\
\text { planejamento Visual. Callis, } 2005 \text { (Obs.: and/or previous editions) }\end{array}$ \\
\hline 19 & 2 & 24 & $\mathrm{EN}$ & $\begin{array}{l}\text { NIELSEN, J.; MACK, R.L. Usability Inspection Methods. John Wiley \& } \\
\text { Sons, } 1994 .\end{array}$ \\
\hline 20 & 2 & 7 & $\mathrm{EN}$ & $\begin{array}{l}\text { COOPER, A. About face: the essentials of user interface design. New } \\
\text { York, NY: Wiley, 2007. (Obs.: and/or previous editions) }\end{array}$ \\
\hline 21 & 2 & 5 & $\mathrm{EN}$ & $\begin{array}{l}\text { The Encyclopedia of Human-Computer Interaction. } \\
\text { http://www.interaction-design.org/encyclopedia/ }\end{array}$ \\
\hline 22 & 2 & 5 & PT & $\begin{array}{l}\text { de SOUZA, C.S.; LEITE, J.C.; PRATES, R.O.; BARBOSA, S.D.J. Proje- } \\
\text { to de Interfaces de Usuário: Perspectivas Cognitiva e Semiótica. Jornada } \\
\text { de Atualização em Informática/CSBC. SBC. } 1999 .\end{array}$ \\
\hline 23 & 2 & 3 & $\mathrm{EN}$ & $\begin{array}{l}\text { LAZAR, J.; FENG, J.H.; HOCHHEISER, H. Research Methods in Hu- } \\
\text { man-Computer Interaction. John Wiley \& Sons, Ltd., } 2010 .\end{array}$ \\
\hline 24 & 2 & 3 & $\begin{array}{l}\text { EN/ } \\
\text { PT }\end{array}$ & PRESSMAN, R.S. Engenharia de Software. McGraw Hill, 2002. \\
\hline
\end{tabular}


Analyzing the data, we can observe that, among the top 10 books cited by educators, only one does not have a version in Portuguese. This reflects a limitation of the Brazilian community regarding teaching material in other languages.

Besides the traditional HCI textbooks, we also see a large number of citations to the seminal Semiotic Engineering book (\#16) in research papers. Although it is not frequently cited in undergraduate courses, semiotic engineering is covered at a more basic level by two references that appear in the top 10, namely \#2 and \#9.

Likewise, Nielsen's and Mack's book on Usability Inspection Methods (\#19) had only 2 citations at the survey, despite being indicated as a complementary reference in the curricula suggested in 2006 [1]. We believe this happens because the book is written in English, which limits its use by some Brazilian students.

We may also note that the Accessibility topic, also suggested by the working group about HCI curricula, is represented in the list mainly by $\# 8$, besides the general introductory textbooks.

Considering references in Portuguese, we highlight that references \#1 (Preece et al.) and \#15 (Norman) have citations both in Portuguese and in English (Table 3).

Table 3. References citation in the undergraduate education survey and in IHC papers, per language (Portuguese and English).

\begin{tabular}{|c|l|l|l|}
\hline$\#$ & \multicolumn{1}{|c|}{ Reference } & \multicolumn{1}{c|}{ Citation in Survey } & \multicolumn{1}{c|}{ Citation in Paper } \\
\hline 1 & $\begin{array}{l}\text { PREECE, J.; ROGERS, Y.; SHARP, H. Interac- } \\
\text { tion design: beyond human-computer interaction. } \\
\text { John Wiley \& Sons, 2013 (+ previous editions) }\end{array}$ & $\begin{array}{l}34 \text { in Portuguese } \\
10 \text { in English } \\
17 \text { in English }\end{array}$ \\
\hline \multirow{2}{*}{15} & $\begin{array}{l}\text { NORMAN, D.A. The Psychology of Everyday } \\
\text { Things. Basic Books, } 1988 / / \text { The Design of } \\
\text { Everyday Things, Basic Book, 1998. }\end{array}$ & $\begin{array}{l}3 \text { in Portuguese } \\
1 \text { in English }\end{array}$ & $\begin{array}{l}0 \text { in Portuguese } \\
5 \text { in English }\end{array}$ \\
\hline
\end{tabular}

The need for HCI textbooks written in Portuguese is a demand of the HCI Brazilian community. In the annual event to discuss HCI Education, WEIHC, this topic is one of the most frequently cited, considering the difficulties that our students have in reading material in English [12]. In addition, the government agencies that evaluate our undergraduate courses demand a certain number of titles to our courses (the best concept is associated to a certain quantity of volumes of 3 titles as basic references and 5 titles as complementary references). The need for distinct titles and our students' difficulties with foreign languages increase the search for (and publication of) textbooks written in Portuguese.

In Table 4 we cross-reference the references listed in Table 2 with the symposium year in which each reference was mentioned. The low numbers reflect the fact that textbooks are only rarely cited in research papers. 
Table 4. Number of citations to each recommended book in IHC papers, per year.

\begin{tabular}{|c|c|c|c|c|c|c|c|c|c|c|c|c|c|}
\hline$\#$ & Reference & 1998 & 1999 & 2000 & 2001 & 2002 & 2004 & 2006 & 2008 & 2010 & 2011 & 2012 & 2013 \\
\hline 1 & $\begin{array}{l}\text { PREECE, J.; ROGERS, Y.; } \\
\text { SHARP, H. }\end{array}$ & & & & & 2 & 1 & 2 & 5 & 3 & 4 & 6 & 2 \\
\hline 2 & BARBOSA, S.D.J.; SILVA, B.S. & & & & & & & & & & 3 & 2 & \\
\hline 3 & $\begin{array}{l}\text { ROCHA, H.V.; } \\
\text { BARANAUSKAS, M.C.C. }\end{array}$ & & & & 1 & 1 & & 1 & 3 & 2 & 2 & 1 & \\
\hline 4 & SHNEIDERMAN, B. & 3 & 3 & 3 & 1 & 2 & & 2 & 2 & & 4 & & \\
\hline 5 & NIELSEN, J.; LORANGER, H. & & & & & & & & & & 2 & & \\
\hline 6 & $\begin{array}{l}\text { CYBIS, W.; BETIOL, A.H.; } \\
\text { FAUST, R. }\end{array}$ & & & & & & & & 1 & 2 & 2 & & \\
\hline 7 & NIELSEN, J. & 2 & 3 & 1 & 4 & 2 & 2 & 3 & 2 & 2 & 4 & & \\
\hline 8 & DIAS, C. & & & & & & & & & 1 & 1 & & \\
\hline 9 & $\begin{array}{l}\text { PRATES, R. O.; BARBOSA, } \\
\text { S.D.J. }\end{array}$ & & & & & & & & 2 & 2 & 2 & 3 & \\
\hline 10 & BENYON, D. & & & & & & & & & & & & \\
\hline 11 & DIX, A. & & 1 & 3 & & & & 2 & & & 2 & & \\
\hline 12 & NIELSEN, J. & & & 1 & 1 & 1 & & & 2 & 1 & & 1 & 1 \\
\hline 13 & $\begin{array}{l}\text { PRATES, R.O.; BARBOSA, } \\
\text { S.D.J. }\end{array}$ & & & & & & & & & & & 1 & \\
\hline 14 & RUBIN, J.; CHISNELL, D. & & & & 1 & 1 & 2 & & & 2 & 1 & & \\
\hline 15 & NORMAN, D.A. & & & 1 & 2 & 1 & & & 1 & & & & \\
\hline 16 & de SOUZA, C.S. & & & & & & & & & 2 & 5 & 9 & 9 \\
\hline 17 & NIELSEN, J.; TAHIR, M. & & & & & & & & & & & & \\
\hline 18 & WILLIAMS, R. & & & & & & & & & & & & \\
\hline 19 & NIELSEN, J.; MACK, R.L. & 2 & & 3 & 4 & 3 & 3 & 2 & 1 & & 3 & 2 & \\
\hline 20 & COOPER, A. & & 1 & & & & & & 2 & 1 & 2 & 1 & \\
\hline 21 & $\begin{array}{l}\text { The Encyclopedia of Human- } \\
\text { Computer Interaction. }\end{array}$ & & & & & & & & & & & 2 & \\
\hline 22 & $\begin{array}{l}\text { de SOUZA, C.S.; LEITE, J.C.; } \\
\text { PRATES, R.O.; BARBOSA, } \\
\text { S.D.J. }\end{array}$ & & & & & 1 & 2 & 1 & & & 1 & & \\
\hline 23 & $\begin{array}{l}\text { LAZAR, J.; FENG, J.H.; } \\
\text { HOCHHEISER, H. }\end{array}$ & & & & & & & & & & & 2 & \\
\hline 24 & PRESSMAN, R.S. & & & & & 2 & & & & & 1 & & \\
\hline
\end{tabular}

As we can see, some books that are well known internationally (\#1, \#4, \#7 and \#19) appear much more frequently ${ }^{6}$ in the conference papers than other books. This is an expected result, because these references are widely recommended and provide a basis to teach and learn diverse HCI topics. Another textbook, Interação HumanoComputador (\#2), written in Portuguese, has constantly appeared since its first edition in 2010. Other references are more infrequent, and appear in papers whose topics resemble the topics covered by the book.

\subsection{HCI around the Country}

The IHC conference series is itinerant. Considering the dimensions of Brazil, $\mathrm{CEIHC} / \mathrm{SBC}$ has held it in distinct regions of the country. The main purpose is to

6 Although some textbooks have a seemingly large number of occurrences in research papers, it is important to notice that we did not count references in all 261 papers published at IHC, but only those which were also mentioned in the educational survey. 
promote $\mathrm{HCI}$ research and practice, and to allow community members - professors, researchers, students and practitioners - or anyone interested that lives in the region to participate more thoroughly, which is often very difficult (for example, when the event is held in the South of the country it becomes very costly for those who live in the North or in the Northeast to attend, and vice versa). Specifically related to HCI education, the mobility of the event raises opportunities for HCI faculty (novices or not) to be in contact with the most recent research developed in the country, promoting more advanced discussions in the classroom. WEIHC also provides an opportunity for the local faculty to discuss, to collaborate and to share with the community their classroom challenges. Figure 4 shows the Brazilian states where IHC took place from 1998 to 2013 (the numbers in each state indicate how many times the conference was held there, and the colors represent the five different geographic regions), as well as a timeline with the number of papers published at each event.
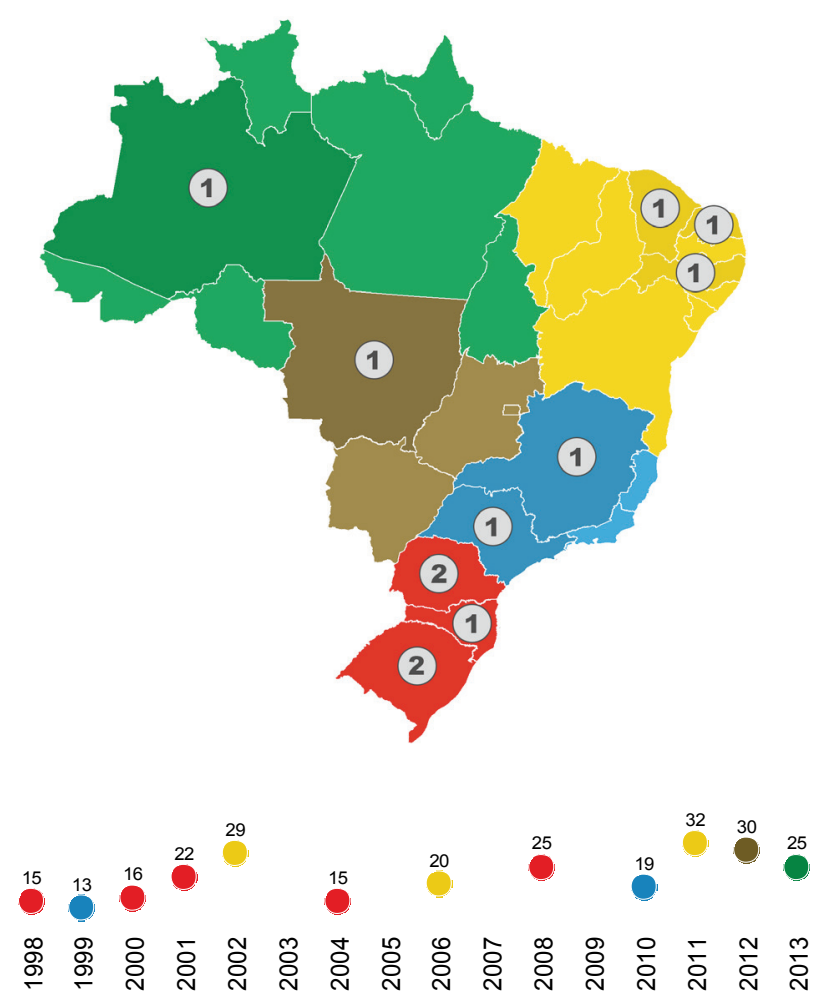

Figure 4. States where IHC was held, how many times in each state, and a timeline with the number of full papers published at each event (until 2013). 
Publications per Region

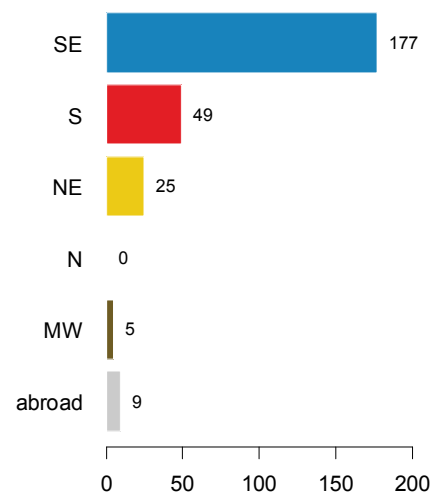

Respondents per Region

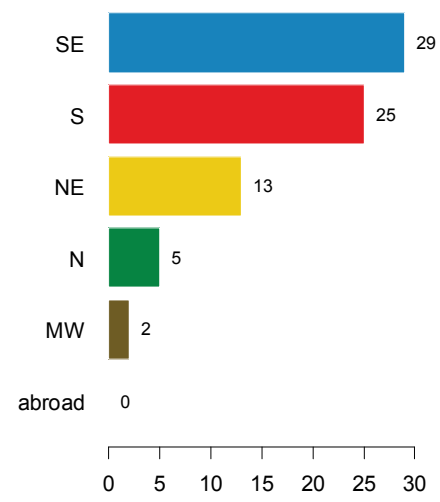

Figure 5. Distribution of publications of the most productive authors (of at least 4 publications) by region, until 2013 (left) and of the respondents of the 2013 survey (right).

As depicted in Figure 5, we may note that most of the HCI researchers in Brazil who publish at IHC are located in the Southeast region. Figure 6 depicts the evolution of the number of papers per region, over time.

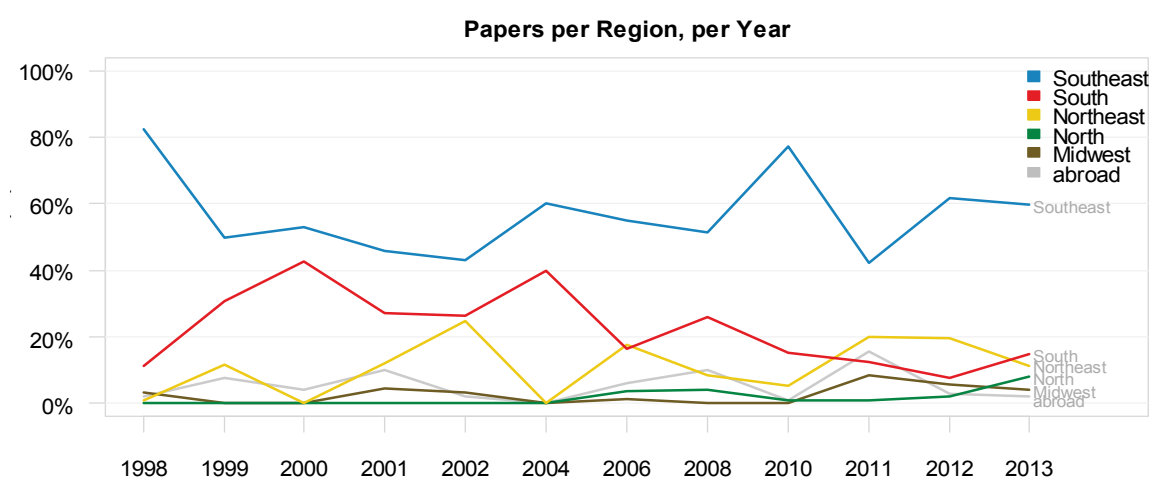

Figure 6. Number of papers per region, per year.

Contrasting Figure 6 and the timeline depicted in Figure 4, we see that the number of papers in the regions where IHC is held often increases (see, for instance, increases in the number of papers from the Northeast in 2002, 2006, and 2011; from the South in 2000 and 2004; and from the Southeast in 2010), which motivates us to keep moving the event around the country. 


\section{$5 \quad$ Highlighted Cases: Semiotic Engineering and Accessibility}

Although we do not have temporal data on the evolution of topics taught in undergraduate classes, we can single out two interesting cases: semiotic engineering and accessibility.

Semiotic engineering [13] is a theory of HCI that was developed in the $90 \mathrm{~s}$ at PUC-Rio (in Rio the Janeiro, in the Southeast region of the country) and has been consistently developed over the years and expanded to other geographic states, e.g. one state of the same region (Minas Gerais), states in other regions (South and Northeast), and even from abroad. Figure 7 depicts the states where the authors of the 34 semiotic engineering papers are affiliated. ${ }^{\text {? }}$

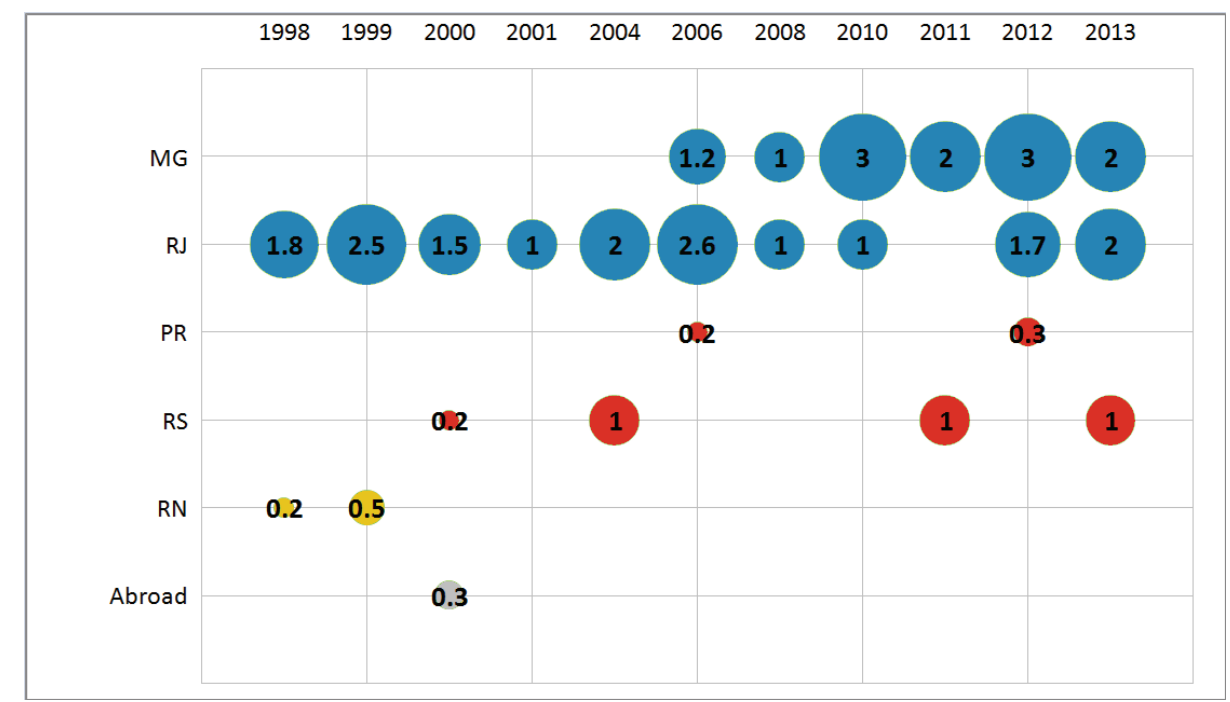

Figure 7. Semiotic engineering papers over the years, per state and region.

From 2000 on, made its way into both graduate and undergraduate courses, starting at the university where it originated. In 2007, the reference curriculum included semiotic engineering as a topic in undergraduate courses and, in our survey in 2013, it was a topic in 21 courses (including more specific topics, such as communicability), below only general HCI topics, such as interface, evaluation, human-computer interaction, accessibility, usability, and design. The influence of semiotic engineering may also be due to the publication of a variety of books and teaching material throughout the years (tutorials in 1999, 2003 and 2007; research books in 2005 and 2009; and textbook in 2010).

Accessibility is also a notable example of the effects of HCI research on HCI teaching, considering not only the research associated to people with disabilities and the diversity of the technology, but also the growing number of functionally illiterate people in Brazil. The topic is not only a concern of the Brazilian HCI community, but

${ }^{7}$ If a paper is coauthored by three people from different states, it counts as one-third for each state. 
more generally of the Brazilian Computer Society (SBC). In 2006, SBC defined five Grand Challenges in Computer Science Research for the following decade, one of which was: "Participative and universal access to knowledge for the Brazilian citizen" [15]. As several research funding opportunities arose to face the Grand Challenges, more initiatives to investigate issues, methods, and technologies related to accessibility were also formed [16]. Figure 8 presents the 20 IHC papers on accessibility over time, across geographic states of its authors.

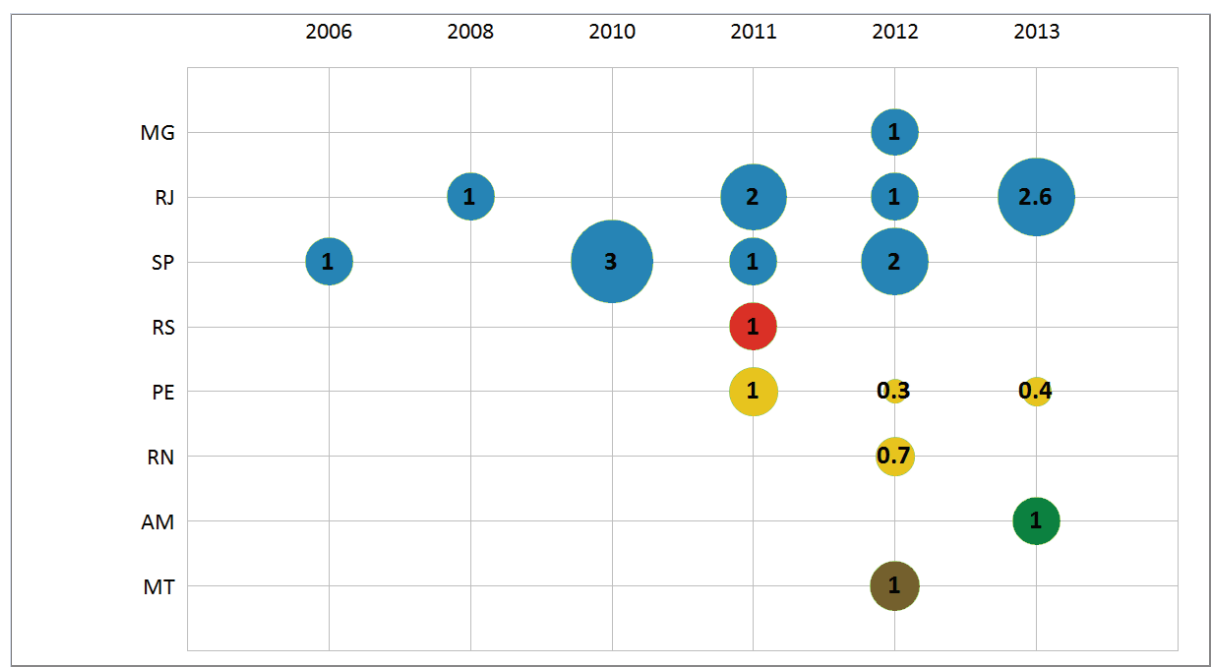

Figure 8. Accessibility papers over the years, per state and region.

In the figure, we see that 2006 was also the year when the first papers on accessibility were published at IHC, and in every IHC since then we see an increasing number of papers on accessibility, with a peak in 2012 and an increasing number of states, from different regions of the country.

\section{Conclusion}

From an analysis of the collected data in context, i.e., taking into account the situation of Brazilian research over time, we concluded that the cross-fertilization between research and education has involved at least three factors: (i) the creation of a reference syllabus by an HCI committee sponsored by the country's CS society (in 2006) [1]; (ii) the publication of educational material in Portuguese (books, technical reports, and class notes and slides), including freely available material [12]; and (iii) research funding opportunities promoted by funding agencies [16].

The work presented here is only one of many possible steps in this area. It is important to mention that the majority of the participants of the survey conducted in 2013 in Brazil had a Computer Science background. Consequently, since HCI is a multidisciplinary field, investigations in the context of other disciplines, such as Design and Psychology, could broaden the analysis of the relation between HCI research and teaching in other contexts. For instance, the profile of the participants could ex- 
plain the low frequency of ergonomics as a topic taught in undergraduate courses. Additionally, most of the participants of IHC are also from Computer Science ${ }^{8}$ which could explain the disappearance of the ergonomics as a topic in the papers published in the event.

The relation with international publication topics is also another perspective to investigate, since many Brazilian researchers choose to publish their works in international events in addition to or instead of publishing at IHC [16]. Investigating the international context is also important because nowadays the Brazilian government offers many opportunities for students to stay at least one year studying abroad during their undergraduate courses. It would be important to verify whether Brazilian HCI courses are preparing students for such international experiences.

The investigation and related discussions presented here can help HCI researchers and educators to better understand - and improve - their role in this field. Since its creation in 1998 [17], the Brazilian community has succeeded in promoting the growth of HCI research and practice in the country. We believe that similar analyses can shed some light in the evolution of $\mathrm{HCI}$ in other countries.

As future work, we want to conduct new editions of the 2013 survey periodically, so that we can analyze the trends in HCI education in Brazil. We want to explore the networks of collaboration and the researchers' migration within the country. For instance, we want to gather data to evaluate the hypothesis that the number of publications in a region is strongly influenced by the migration of former graduate students from the main research poles (Rio, São Paulo, and Rio Grande do Sul) to emerging universities in various states. We also plan to conduct a study of HCI practice in industry, with the goal to understand the mutual influences between research, practice, and education.

\section{$7 \quad$ References}

1. Silveira, M. S., Prates, R. O.: Uma Proposta da Comunidade para o Ensino de IHC no Brasil. In: XIV Workshop sobre Educação em Computação, v. 1, pp. 76-84. Sociedade Brasileira de Computação (2007).

2. Boscarioli, C., Silveira, M. S., Prates, R. O., Bim, S. A., Barbosa, S. D. J.: Currículos de IHC no Brasil: Panorama Atual e Perspectivas. In: XXII Workshop sobre Educação em Computação no XXXIV CSBC, pp. 1294-1303. Sociedade Brasileira de Computação (2014).

3. Hewett, T.; Baecker, R., Card, S., Carey, T., Gasen, J., Mantei, M., Perlman, G., Strong, G., Verplank, W.: ACM SIGCHI Curricula for Human-Computer Interaction. http://old.sigchi.org/cdg/(1992).

4. Churchill, E.F., Bowser, A., Preece, J.: Teaching and Learning Human-Computer Interaction: Past, Present, and Future. ACM Interactions, Mar/Apr 2013, pp. 44-53 (2013).

5. Churchill, E., Preece, J., Bowser, A.: Information on the 2011-2013 research on HCI Education, http://www.sigchi.org/resources/education/2011-educationproject-1/2011-education-project (2013).

${ }^{8}$ For instance, out of the 25 full papers published at IHC 2013, only one was written exclusively by non-CS authors. 
6. Graham, D. A.: Survey of Teaching and Assessment Methods Employed In UK Higher Education Programmes for HCI Courses. In: 7th HCI Educators Workshop, pp. 66-69. University of Central Lancashire, Preston, UK (2004).

7. Yammiyavar, P.: Status of HCI and Usability Research in Indian Educational Institutions In: Human Work Interaction Design: Usability in Social, Cultural and Organizational Context. pp. 21-27. Springer (2012).

8. de Souza, C. S.: Da importância dos Simpósios Brasileiros de Fatores Humanos em Sistemas Computacionais, http://comissoes.sbc.org.br/ce-ihc/documentos/daimportancia-dos-IHCs_2006.html (2013).

9. Gasparini, I., Kimura, M. K., Pimenta, M. S.: Visualizando 15 anos de IHC. In: $12^{\circ}$. Brazilian Symposium on Human Factors in Computing Systems (IHC '13). pp. 238-247. Sociedade Brasileira de Computação (2013).

10. Prates, R. O., Filgueiras, L.: Usability in Brazil. In: Ian Douglas; Liu Zhengjie. (Org.). Global Usability. 1ed. v. 1, pp. 91-110. Springer-Verlag, London (2011).

11. Boscarioli, C., Bim, S. A., Silveira, M. S., Prates, R. O., Barbosa, S. D. J.: HCI Education in Brazil: Challenges and Opportunities. In: M. Kurosu (ed). HCI International. LLCS, vol. 8004, pp. 3-12. Springer (2013).

12. Boscarioli, C., Silveira, M. S., Prates, R. O., Bim, S. A.; Barbosa, S. D. J.: Charting the Landscape of HCI Education in Brazil. In: M. Kurosu (ed). HCI International, LNCS, vol. 8510, pp. 177-186. Springer (2014).

13. de Souza, C.S.: The Semiotic Engineering of Human-Computer Interaction. Cambridge, MA. The MIT Press (2005).

14. de Souza, C.S.; Leitão, C.F.; Prates, R.O.; Silva, E.J.: The semiotic inspection method. In: VII Brazilian symposium on Human factors in computing systems (IHC '06). pp. 148-157. Sociedade Brasileira de Computação (2006)

15. Medeiros, C.B.: Grand Research Challenges in Computer Science in Brazil, Computer, vol.41, no.6, pp.59,65, June 2008.

16. Barbosa, S.D.J.; de Souza, C.S. Are HCI researchers and endangered species in Brazil? ACM Interactions, Mar/Jun 2011, pp. 69-71 (2011).

17. Prates, R., Barbosa, S. D. J., da Silveira, M., de Souza, C., Baranauskas, C., Maciel, C., Furtado, E., Anacleto, J., Melo, P., Kujala, T.: HCI community in Brazil- sweet 16!. ACM Interactions, vol. 20, n. 6, pp. 80-81 (2013). 